\title{
Preliminary molecular phylogeny of the diatom genus Nupela with the descrip- tion of a new species and consideration of the interrelationships of taxa in the suborder Neidiineae D.G. Mann sensu E.J. Cox
}

\author{
Maxim S. KulikovskiY ${ }^{1 *}$, Yevhen I. Maltsev ${ }^{1}$, Anton M. Glushchenko ${ }^{1}$, Evgeniy \\ S. Gusev ${ }^{1}$, Dmitry A. Kapustin ${ }^{1}$, Irina V. KuZnetsova ${ }^{1}$, Larisa Frolova ${ }^{2} \&$ John \\ P. KOCIOLEK ${ }^{3,4}$
}

\author{
${ }^{1}$ K.A. Timiryazev Institute of Plant Physiology RAS, IPP RAS, 35 Botanicheskaya St., Moscow, 127276, Russia; \\ *Corresponding author: max-kulikovsky@yandex.ru \\ ${ }^{2}$ Kazan Federal University, Kremlevskaya St. 18, Kazan, 420008, Russia \\ ${ }^{3}$ Museum of Natural History and ${ }^{4}$ Department of Ecology and Evolutionary Biology University of Colorado,
} Boulder, Colorado, 80309 USA

\begin{abstract}
Molecular investigation of genera Nupela and Brachysira is conducted using strains from Indonesia and Vietnam. New species from the genus Nupela indonesica sp. nov. is described using combined approach. Nupela lesothensis (Schoeman) Lange-Bertalot is investigated using molecular data too. Phylogenetic analysis shows that Nupela and Brachysira are not closest genera. Morphology of Nupela and it differences from Brachysira is discussed. The genus Nupela is differs from all other diatom taxa by having coalescent hymenes ouside of areolae but not inside. Facultative development of raphe between different Nupela species is discussed.
\end{abstract}

Key words: Brachysira, diatoms, morphology, molecular investigation, Nupela, phylogeny, taxonomy

\section{INTRODUCTION}

Nupela is a freshwater diatom genus established by VYVERMAN \& COMPÈRE (1991) with $N$. giluwensis Vyverman et Compère, as the type species. The new genus and species were described originally from high elevation ponds in Papua New Guinea. Vyverman \& COMPÈRE (1991, p. 178) postulated that this very interesting species and new genus "could find its place in the suborder Neidiineae, somewhere near or in the families Brachysiraceae or Diadesmidiaceae". Nupela shares some morphological features with both Brachysira and Diadesmis such as transapically elongated areolae, relatively few areolae per striae, presence of ridge or a hyaline area at the junction of valve face and mantle and simple or inconspicuous proximal raphe fissures. This genus was described as a naviculoid biraphid taxon (VYVERMAN \& COMPÈRE 1991).

Since its original description, many new species were transferred to Nupela mainly on the basis of striae and areolae morphology. Lange-Bertalot with coauthors (LANGE-BERTALOT 1993; LANGE-BERTALOT \& Moser 1994; Metzeltin \& Lange-Bertalot 1998;
Moser et al. 1998; Lange-Bertalot \& GenKal 1999; RUMrich et al. 2000) transferred to the genus Nupela many monoraphid species from the previously catch-all genus Achnanthes sensu lato. Presence of unique morphological features allowed them to place biraphid and monoraphid taxa in the same genus, even though this was not common practice. Well-known species such as Nupela impexiformis (Lange-Bertalot) Lange-Bertalot, N. subrostrata (Hustedt) Potapova, N. lapidosa (Krasske) Lange-Bertalot, N. pennsylvanica (R.M. Patrick) Potapova, N. poconoensis (R.M. Patrick) Potapova, N. biconfusa (Van Landingham) C.E. Wetzel et Ector and many others were transferred to Nupela. From the biraphid diatom, species previously described as Anomoeoneis Pfitzer, Brachysira Kützing, Navicula Bory, Neidium Pfitzer, Rhoicosphaenia Grunow and Stauroneis Ehrenberg, were also transferred to this genus. At present, there are less than 100 species reported in this genus; 48 species records are listed in Catalogue of Diatom Names (FOURTANIER \& KocIOLEK 2011), and 80 have been flagged as accepted taxonomically (GUIRY \& GUIRY 2020).

The characteristics of the genus Nupela are small frustule size, generally less than $25 \mu \mathrm{m}$, valves are narrowly 
elliptical with strongly capitate ends, slightly curved transapically, the central area is asymmetric, and may extend nearly to the valve margin. Although Vyverman and Compere (1991, p. 178) indicate that, "An inner, centrally perforated hymen is present in each areola" it is generally considered that the areolae of Nupela species are covered by hymenes externally. Other features of the genus include large external and small internal openings of the areolae, the areolae are arranged in striae of variable length, raphe fissures slightly undulate, raphe endings inconspicuous, terminal fissures sharply curved into one side of valve, proximal endings $\mathrm{T}$-shaped located in a moderately inflated central nodule, the external terminal raphe endings in most cases form a double hook or occasionally a single hook, valves have obvious siliceous thickenings on the external surface, and either biraphid or monoraphid frustules (VYVERMAN \& COMPERE 1991; Potapova et al. 2003; Siver et al. 2007). The genus Nupela does not show substrate preferences and it has been found on rocks, wood and saturated soils; does not show a $\mathrm{pH}$ preference, being present both in slightly acidic (PotAPova 2013) and alkaline waters (BAHLS 2011).

From this long list of features, the main morphological characteristics that diagnose this genus are the morphology of striae and areolae with hymenes, that are covered externally, distinguishing them from for all other naviculoid and achnanthoid genera (KuLIKOVSKIY et al. 2016). Areolae are broader externally versus internally (Potapova 2011).

The suborder Neidiineae was proposed by D.G. MANN IN Round et al. (1990), for a group of naviculoid diatoms (in the order Naviculales Bessey), that included a number of new families. Amongst the families D.G. Mann included in his new suborder are Berkeleyaceae, Cavinulaceae, Cosmioneidaceae, Scolioneidaceae, Diadesmidiaceae Amphipleuraceae, Brachysiraceae, Neidiaceae and Scoliotropidaceae; only the latter two had been previously described. In his description of this diverse suborder (MANN in Round et al. 1990, p. 657), many features of the group were described as "various", while the feature of internal hymenate occlusions was specified.

Nupela was described the year following publication of Round et al. (1990), and while there is ample evidence that the hymenate occlusions of Nupela species are positioned on the exterior of the valves (PotAPOVA et al. 2003). E. Cox, in her revised classification of the diatoms (Cox 2015), assigned Nupela to the family Brachysiraceae. This assignment was made even though nearly all of the features listed for the family are not found in Nupela.

The aims of this publication include 1) to describe a new species of Nupela from Indonesia, 2) to use molecular data from this new species and a second species transferred to Nupela to assess the phylogenetic position of the genus and 3 ) to reassess the Neidiineae to see how the suborder reflects a natural classification of the taxa assigned there.

\section{Materials AND Methods}

Samples from Indonesia were collected by I.I. Ivanov and from Vietnam by M. Kulikovskiy and E. Gusev. Water mineralization and temperature measurements were performed using the Hanna Combo (HI 98129) device, Hanna Instruments, Inc., USA. List of all strains examined in this study with their GenBank accession numbers and geographic position of sample areas with measured ecological parameters presented in Table 1. Data that were not determined are indicated with N.D.

A subsample of each collection was added to WC liquid medium (Guillard \& Lorenzen 1972). Monoclonal strains were established by micropipetting single cells under an inverted microscope. Non-axenic unialgal cultures were maintained in WC liquid medium at $10{ }^{\circ} \mathrm{C}$ in a growth chamber with a $12: 12$ $\mathrm{h}$ light:dark photoperiod.

Strains for LM and SEM investigations have been processed by means of a standard procedure involving treatment with $10 \% \mathrm{HCl}$ and concentrated hydrogen peroxide $(\approx$ $37 \%$ ) to oxidize organic matter. After treatment, the sample was washed with deionized water four times at $12 \mathrm{~h}$ intervals. Permanent diatom preparations have been mounted in Naphrax ${ }^{\circledR}$. Light microscopic (LM) observations have been performed by means of a Zeiss Axiovert and Zeiss Axioscope A1 microscope equipped with an oil immersion objective (100/n.a. 1.4, DIC). Valve ultrastructure was examined with a JSM-6510LV field emission scanning electron microscope and EMS FF200- $\mathrm{Cu}-50$ (USA) transmission electron microscope (Borok, Russia). The stubs were sputter coated with $50 \mathrm{~nm}$ of Au by means of a Eiko IB 3. Samples, cultures and slides are deposited in the collection of Maxim Kulikovskiy at the Herbarium of the Institute of Plant Physiology Russian Academy of Science, Moscow, Russia.

Total DNA of monoclonal cultures of Nupela strains was extracted using InstaGene ${ }^{\mathrm{TM}}$ Matrix according to the manufacturer's protocol 2.2 "DNA preparation from cultured mammalian cells". Fragments of $18 \mathrm{~S}$ rDNA (306-433 bp, including V4 domain), and partial rbcL plastid genes (1062-1129 bp) were amplified using primers D512for and D978rev from ZimmERman et al. (2011) for 18S rDNA fragments and rbcL40+ from RUCK \& THERIOT (2011) and rbcL1255- from ALVERSON et al. (2007) for rbcL fragments.

Amplifications of the 18S rDNA fragments and partial rbcL gene fragment were carried out using the premade mix ScreenMix (Evrogen, Russia) for the polymerase chain reaction (PCR). The conditions of amplification for $18 \mathrm{~S} \mathrm{rDNA}$ fragments were: an initial denaturation of $5 \mathrm{~min}$ at $95{ }^{\circ} \mathrm{C}$, followed by 35 cycles at $94{ }^{\circ} \mathrm{C}$ for denaturation $(30 \mathrm{~s}), 52^{\circ} \mathrm{C}$ for annealing $(30 \mathrm{~s})$ and $72{ }^{\circ} \mathrm{C}$ for extension $(50 \mathrm{~s})$, and a final extension of $10 \mathrm{~min}$ at $72^{\circ} \mathrm{C}$. The conditions of amplification for partial rbcL were: an initial denaturation of $5 \mathrm{~min}$ at 95 ${ }^{\circ} \mathrm{C}$, followed by 45 cycles at $94{ }^{\circ} \mathrm{C}$ for denaturation (30 s), 59 ${ }^{\circ} \mathrm{C}$ for annealing $(30 \mathrm{~s})$ and $72{ }^{\circ} \mathrm{C}$ for extension $(80 \mathrm{~s})$, and a final extension of $10 \mathrm{~min}$ at $72{ }^{\circ} \mathrm{C}$.

The resulting amplicons were visualized by horizontal agarose gel electrophoresis (1.5\%), colored with SYBR Safe (Life Technologies, United States). Purification of DNA fragments was performed with the ExoSAP-IT kit (Affimetrix, USA) according to the manufacturer's protocol. $18 \mathrm{~S}$ rDNA fragments and partial rbcL gene were decoded from two sides using forward and reverse PCR primers and the Big Dye system (Applied Biosystems, USA), followed by electrophoresis using a Genetic Analyzer 3500 sequencer (Applied Biosystems).

Editing and assembling of the consensus sequences were carried out by comparing the direct and reverse chromatograms 


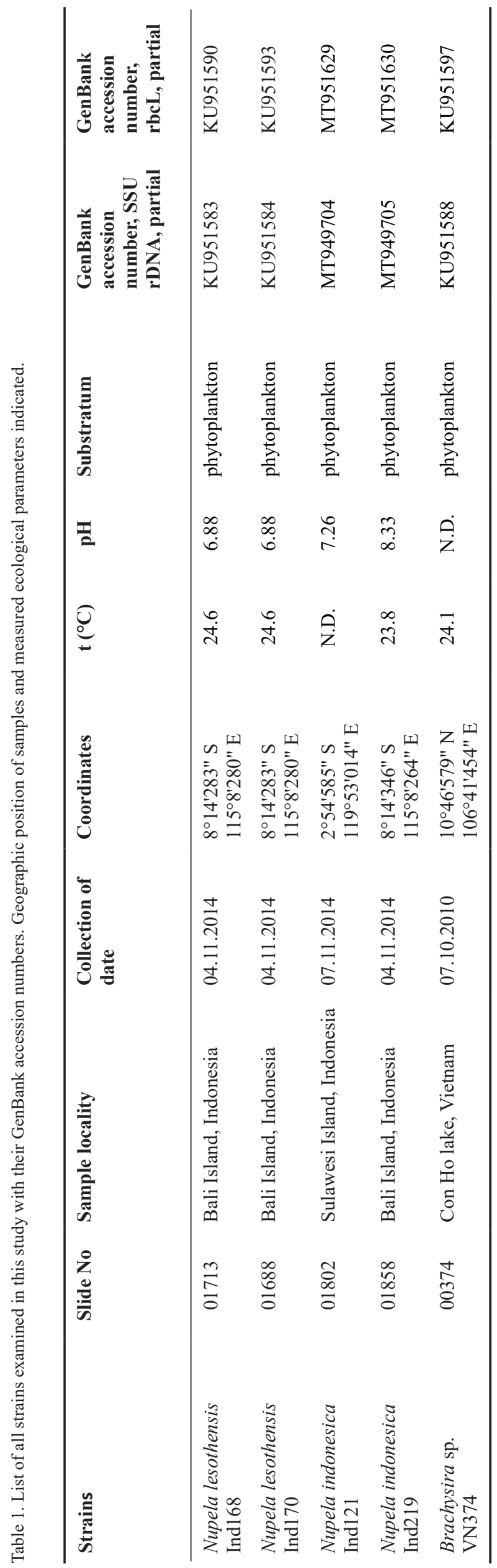

using the Ridom TraceEdit program (ver. 1.1.0) and Mega7 (Kumar et al. 2016). Newly determined sequences and DNA fragments from 161 other diatoms, which were downloaded from GenBank (taxa, strain numbers (if available) and Accession Numbers are given in Supplementary table 1), were included in the alignments. Four centric diatom species were chosen as the outgroups.

The nucleotide sequences of the $18 \mathrm{~S}$ rDNA and rbcL genes were aligned separately using the Mafft v7 software and the E-INS-i model (КАтOH \& ТоH 2010). For the protein-coding sequences of the rbcL gene, we checked that the beginning of the aligned matrix corresponded to the first position of the codon (triplet). The resulting alignments had lengths of 552 (18S rDNA) and 1254 (rbcL) characters.

A phylogenetic tree was inferred by Bayesian inference (BI) using MrBayes version 3.2.7 (RoNQUIST et al. 2012). For each of the alignment partitions, the most appropriate substitution model was estimated using the Bayesian information criterion (BIC) as implemented in jModelTest 2.1.10 (DARriBA et al. 2012). This BIC-based model selection procedure selected the following models, shape parameter $\alpha$ and a proportion of invariable sites (pinvar): $\operatorname{TrN}+\mathrm{G}, \alpha=0.2830$ for $18 \mathrm{~S}$ rDNA; TIM1 $+\mathrm{I}+\mathrm{G}, \alpha=0.5220$ and pinvar $=0.5780$ for the first codon position of the rbcL gene; TIM1 ef $+\mathrm{I}+\mathrm{G}, \alpha$ $=0.2620$ and pinvar $=0.6680$ for the second codon position of the $\mathrm{rbcL}$ gene; $\mathrm{TVM}+\mathrm{I}+\mathrm{G}, \alpha=0.7750$ and pinvar $=0.0760$ for the third codon position of the rbcL gene. We used the HKY model of nucleotide substitution instead of TrN and TIM1ef, GTR instead of TIM1 and TVM, given that they were the best matching model available for Bayesian inference method. The parameters-estimated convergence, effective sample size (ESS) and burn-in period were checked using the software Tracer ver. 1.7.1. (DRUMmond \& RAMBAUT 2007). Three "hot" and one "cold" Markov chains were run for $1 \times 10^{6}$ cycles in two repetitions with the selection of each 200th generated tree. The initial $25 \%$ of the trees were removed, the rest retained to reconstruct a final phylogeny. The phylogenetic tree and posterior probabilities of its branching were obtained on the basis of the remaining trees, having stable estimates of the parameter models of nucleotide substitutions and likelihood. Maximum Likelihood (ML) analysis was performed using the program RAxML (STAMATAKIs et al. 2008). The nonparametric bootstrap analysis with 1000 replicas was used. The statistical support values were visualized in FigTree ver. 1.4.4 and Adobe Photoshop CC (19.0).

\section{RESULTS}

Nupela indonesica Kulikovskiy, Maltsev, Glushchenko et Kociolek sp. nov. (Figs 1-41)

Description: Valve outlines lanceolate with more or less protracted ends, subrostrate to subcapitate. Valves biraphid. Length $8.6-10.8 \mu \mathrm{m}$, breadth 3.5-4.6 $\mu \mathrm{m}$. Valves with filiform raphes lying in a narrow, almost linear axial area, becoming conspicuously expanded from distal parts towards the central area. Distal raphe ends present on valve face and slightly curved or hooked to mantle. Striae difficult to discern in LM. Striae radiate throughout, 46-50 in $10 \mu \mathrm{m}$, areolae 68-70 in $10 \mu \mathrm{m}$. Striae consist of many (greater than five) areolae. The large lanceolate central area is irregularly rugose. Areolae larger externally then internally. 
In the SEM, external views (Figs 13-16, 33-36) frustules can be heterovalvate, with some valves having more elongate (e.g. Fig. 33) or shorter (Figs 13, 34) raphe systems. Axial area narrowly lanceolate, widening to form a variably-shaped and sized central area that can extend unidirectionally to the margin with (Figs 13, 14, 33) or without (Fig. 34) isolated areolae being present. Raphe is filiform, more or less straight to weakly undulate. Proximal raphe ends straight (Figs 13, 14) or bent slightly in the same direction (Figs 33, 35). Distal raphe ends may be deflected onto the mantle (Figs 15, $33,36)$ or terminate before reaching the apex of the valve (Figs 16, 34, 35). Striae are radiate the entire length of the valve, quadrate or ellipsoidal in shape. The striae are interrupted between the valve face and mantle by a narrow hyaline area on the valve margin. On the mantle striae are composed of a single areola.

Internally (Figs 37-41) the central nodule can be small and round (e.g. Figs 37, 38) or extended and shallower (Fig. 39). Proximal raphe ends are straight, (Figs 40, 41) and distal ends terminate as small but distinct helictoglossae (Figs 37-39). Areolae are ellipsoidal, smaller than their external expressions.

Holotype (designated here): slide no 01802b (Fig. 7 represents the holotype) in herbarium of MHA, Main Botanical Garden Russian Academy of Science, Moscow, Russia.

Type strain: Strain Ind 121, isolated in from the sample $\mathrm{S} 1 / 1$, deposited at the culture collection of the Laboratory of molecular systematics of aquatic plants, Timiryazev Institute of Plant Physiology Russian Academy of Science, Moscow, Russia.

Type locality: Indonesia, Sulawesi Island, sample S1/1, phytoplankton (2॰54'585"S 11953'014"E), leg. I.I. Ivanov, coll. date 07.11.2012.

Etymology: The specific epithet "indonesica" refers to the name of the country where this species was observed. Distribution. Indonesia, Sulawesi Island (type locality) and Bali Island (strain Ind219, slide no 01858).

\section{Nupela lesothensis (Schoeman) Lange-Bertalot 2000} (Figs 42-72, 78-85)

Basionym: Rhoicosphenia lesothensis Schoeman 1973.

Description: Valves elliptical-lanceolate, with protracted, rostrate apices. Length $11-15.5 \mu \mathrm{m}$, breadth $3.8-5 \mu \mathrm{m}$. Striae not evident the light microscope.

In the SEM, the valve exterior (Figs 54-56, 78-81) has a filiform raphe that is straight, with straight proximal ends (Figs 54, 55, 78-70) and hooked to "?"-shaped distal ends that curve onto the mantle (Figs 54, 56, 78, $79,81)$. The axial area is narrow at the ends, widening towards the center to form an unidirectionally-expanded central area. Striae $45-46$ in $10 \mu \mathrm{m}$, are radiate at the center of the valve, becoming convergent at the ends. Areolae are quadrate to ellipsoidal in shape. Areolae
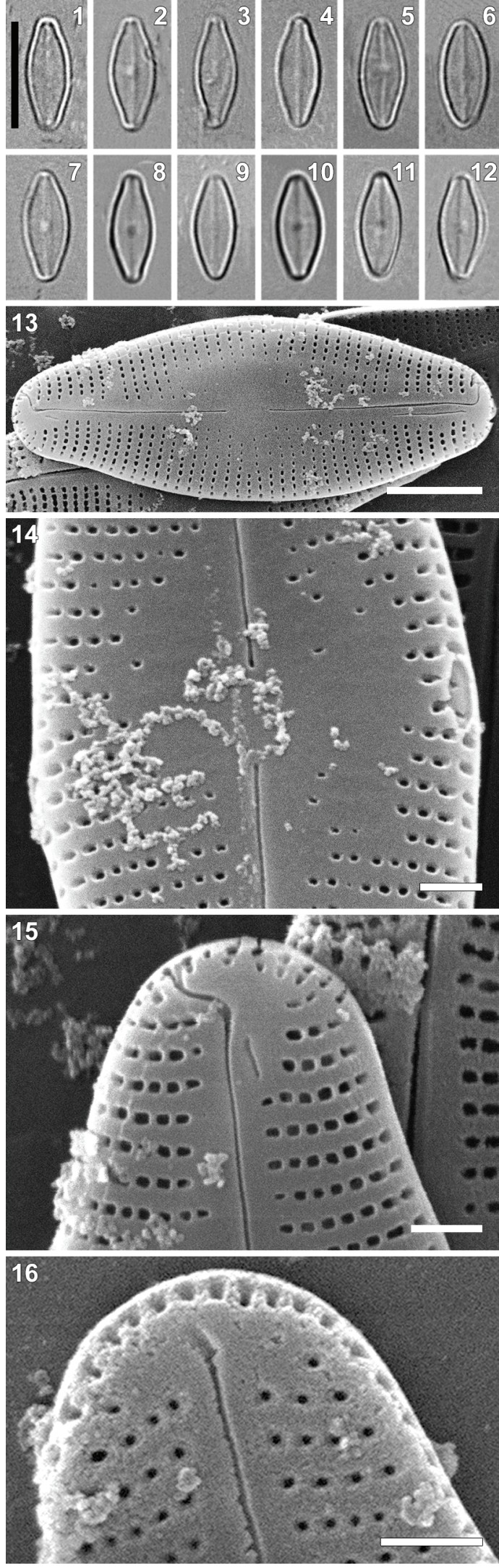

Figs 1-16. Nupela indonesica Kulikovskiy, Maltsev, Glushchenko et Kociolek sp. nov. Strain Ind 121. Slide no 01802. (1-12) LM, DIC, size diminution series. (13-16) SEM, external views, (13) the whole valve, (14) central area, $(15,16)$ valves ends. Figure 7 is of the holotype. Scale bars $10 \mu \mathrm{m}$ (1-12), $2 \mu \mathrm{m}$ (13), $0.5 \mu \mathrm{m}$ (14-16). 


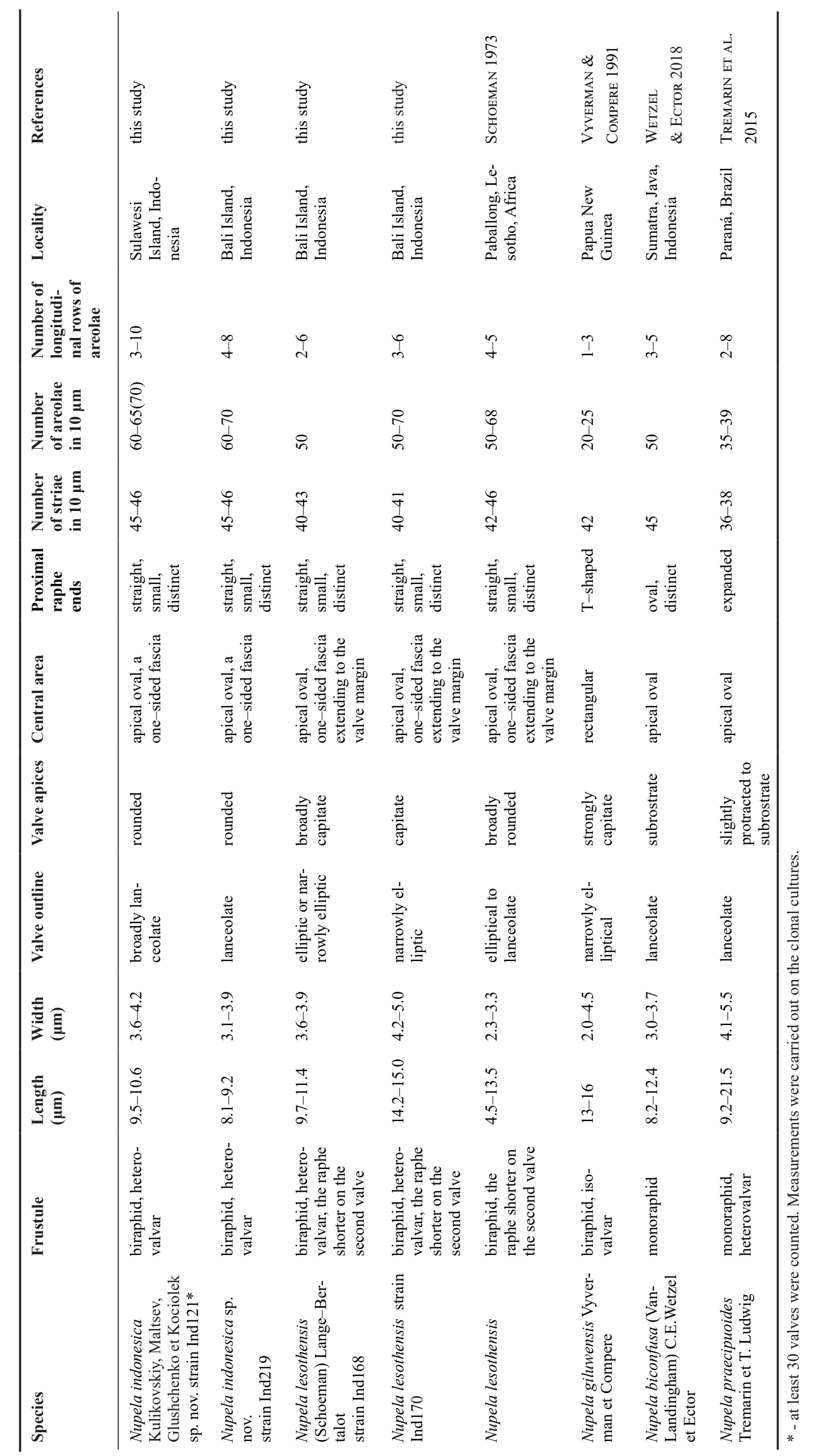


Table 3. Percent similarity ( $p$-distance) matrix of 21 strains on the basis of the partial $18 \mathrm{~S}$ rRNA gene including the V4 barcoding subregion (433 bp).

\begin{tabular}{|c|c|c|c|c|c|c|c|c|c|c|c|c|c|c|c|c|c|c|c|c|c|c|}
\hline & Strain & 1 & 2 & 3 & 4 & 5 & 6 & 7 & 8 & 9 & 10 & 11 & 12 & 13 & 14 & 15 & 16 & 17 & 18 & 19 & 20 & 21 \\
\hline 1 & Nupela indonesica Ind 121 & - & & & & & & & & & & & & & & & & & & & & \\
\hline 2 & Nupela indonesica Ind219 & 99.6 & - & & & & & & & & & & & & & & & & & & & \\
\hline 3 & Nupela lesothensis Ind 168 & 98.5 & 98.7 & - & & & & & & & & & & & & & & & & & & \\
\hline 4 & Nupela lesothensis Ind 170 & 98.4 & 98.7 & 100 & - & & & & & & & & & & & & & & & & & \\
\hline 5 & Neidium affine UTEX FD127 & 91.3 & 90.3 & 90.1 & 89.6 & - & & & & & & & & & & & & & & & & \\
\hline 6 & Neidium amphigomphus JAR89 G6Run12 & 91.4 & 90.3 & 90.0 & 89.4 & 97.7 & - & & & & & & & & & & & & & & & \\
\hline 7 & Neidium bisulcatum UTEX FD417 & 91.0 & 90.1 & 89.9 & 89.4 & 98.6 & 98.0 & - & & & & & & & & & & & & & & \\
\hline 8 & Neidium dilatatum JAR70 A4Run13 & 91.2 & 90.2 & 89.8 & 89.3 & 98.1 & 98.4 & 98.2 & - & & & & & & & & & & & & & \\
\hline 9 & Neidium fossum JAR83 D5Run12 & 91.0 & 90.0 & 89.6 & 89.2 & 99.5 & 97.6 & 98.3 & 98.1 & - & & & & & & & & & & & & \\
\hline 10 & Neidium hitchcockii JAR89 G4Run12 & 91.8 & 90.5 & 90.4 & 89.8 & 97.9 & 98.4 & 97.7 & 98.7 & 97.7 & - & & & & & & & & & & & \\
\hline 11 & Neidium longiceps CANA:108131 D5R18 & 91.3 & 90.3 & 90.0 & 89.5 & 99.7 & 97.9 & 98.7 & 98.4 & 99.5 & 97.9 & - & & & & & & & & & & \\
\hline 12 & Neidum sacoense CANA: 108122 A5R17 & 91.0 & 89.9 & 89.6 & 89.1 & 99.4 & 97.7 & 98.4 & 98.2 & 99.3 & 97.7 & 99.5 & - & & & & & & & & & \\
\hline 13 & $\begin{array}{l}\text { Diploneis cf. cheronensis GU44AY-6 } \\
\text { Dip. ef crab-2 }\end{array}$ & 92.7 & 92.1 & 92.9 & 92.5 & 90.4 & 90.2 & 90.3 & 90.0 & 90.5 & 90.5 & 90.7 & 90.4 & - & & & & & & & & \\
\hline 14 & Diploneis cf. smithii KSA2015-30 oval-B6 & 93.0 & 92.5 & 93.1 & 92.9 & 89.2 & 89.9 & 89.4 & 89.7 & 89.5 & 90.1 & 89.8 & 89.5 & 94.5 & - & & & & & & & \\
\hline 15 & Diploneis cf. smithii GU44AY6 & 92.5 & 92.2 & 92.2 & 91.9 & 87.4 & 88.5 & 88.2 & 88.3 & 88.5 & 88.6 & 88.6 & 88.3 & 93.7 & 97.4 & & & & & & & \\
\hline 16 & Diploneis parca KSA2015-49 oval-ED-2 & 92.9 & 92.6 & 92.7 & 92.5 & 88.8 & 88.4 & 88.7 & 88.8 & 88.8 & 89.1 & 89.1 & 88.8 & 93.6 & 97.3 & 95.2 & - & & & & & \\
\hline 17 & Diploneis sp. PackChannelPlank Diplo-1 & 93.2 & 92.5 & 93.0 & 92.6 & 89.9 & 90.1 & 90.1 & 90.1 & 90.2 & 90.1 & 90.4 & 90.2 & 94.9 & 94.5 & 93.4 & 93.5 & - & & & & \\
\hline 18 & Diploneis sp. KSA2015-14 oval-J31 & 92.8 & 92.5 & 92.8 & 92.5 & 88.8 & 89.4 & 89.1 & 89.2 & 89.2 & 89.6 & 89.5 & 89.2 & 93.7 & 97.2 & 95.4 & 97.6 & 93.9 & - & & & \\
\hline 19 & Diploneis sp. 21IV14-2A oval penn-B1 & 93.1 & 92.7 & 93.1 & 92.8 & 89.3 & 89.9 & 89.5 & 89.9 & 89.6 & 90.2 & 89.9 & 89.6 & 94.4 & 97.6 & 95.8 & 97.1 & 94.1 & 97.4 & - & & \\
\hline 20 & Diploneis subovalis UTEX FD282 & 91.6 & 91.2 & 91.4 & 91.2 & 88.4 & 88.8 & 88.8 & 89.0 & 88.8 & 89.5 & 89.0 & 88.7 & 93.0 & 95.9 & 94.2 & 96.0 & 92.6 & 95.5 & 95.5 & & \\
\hline 21 & Diploneis vacillans KSA2015-11 peanut-E14 & 93.0 & 92.5 & 93.1 & 92.8 & 89.8 & 90.4 & 90.1 & 90.5 & 90.2 & 90.7 & 90.5 & 90.2 & 94.4 & 97.8 & 96.6 & 96.9 & 94.4 & 96.6 & 97.9 & 95.8 & - \\
\hline
\end{tabular}

Table 4. Percent similarity ( $p$-distance) matrix of 21 strains on the basis of the partial ribulose-1,5-bisphosphate carboxylase, large subunit (377 amino acids).

\begin{tabular}{|c|c|c|c|c|c|c|c|c|c|c|c|c|c|c|c|c|c|c|c|c|c|c|}
\hline & Strain & 1 & 2 & 3 & 4 & 5 & 6 & 7 & 8 & 9 & 10 & 11 & 12 & 13 & 14 & 15 & 16 & 17 & 18 & 19 & 20 & 21 \\
\hline 1 & Nupela indonesica Ind121 & & & & & & & & & & & & & & & & & & & & & \\
\hline 2 & Nupela indonesica Ind219 & 99.7 & - & & & & & & & & & & & & & & & & & & & \\
\hline 3 & Nupela lesothensis Ind168 & 98.1 & 97.7 & - & & & & & & & & & & & & & & & & & & \\
\hline 4 & Nupela lessothensis Ind170 & 98.0 & 97.7 & 100 & - & & & & & & & & & & & & & & & & & \\
\hline 5 & Neidium affine UTEX FD127 & 94.8 & 94.9 & 94.1 & 93.8 & - & & & & & & & & & & & & & & & & \\
\hline 6 & Neidium amphigomphus JAR89 G6Run12 & 94.5 & 94.4 & 93.6 & 93.2 & 99.7 & - & & & & & & & & & & & & & & & \\
\hline 7 & Neidium bisulcatum UTEX FD417 & 94.5 & 94.6 & 93.9 & 93.5 & 99.7 & 100 & - & & & & & & & & & & & & & & \\
\hline 8 & Neidium dilatatum JAR70 A4Run13 & 94.7 & 94.7 & 93.9 & 93.5 & 100 & 99.7 & 99.7 & - & & & & & & & & & & & & & \\
\hline 9 & Neidium fossum JAR83 D5Run12 & 94.7 & 94.7 & 93.9 & 93.5 & 100 & 99.7 & 99.7 & 100 & - & & & & & & & & & & & & \\
\hline 10 & Neidium hitchcockii JAR89 G4Run12 & 94.5 & 93.8 & 93.6 & 93.2 & 98.9 & 98.6 & 98.6 & 98.9 & 98.9 & - & & & & & & & & & & & \\
\hline 11 & Neidium longiceps CANA:108131 D5R18 & 94.7 & 94.7 & 93.9 & 93.5 & 100 & 99.7 & 99.7 & 100 & 100 & 98.9 & - & & & & & & & & & & \\
\hline 12 & Neidium sacoense CANA:108122 A5R17 & 94.7 & 94.7 & 93.9 & 93.5 & 100 & 99.7 & 99.7 & 100 & 100 & 98.9 & 100 & - & & & & & & & & & \\
\hline 13 & $\begin{array}{l}\text { Diploneis cf. cheronensis GU44AY-6 } \\
\text { Dip. cf crab-2 }\end{array}$ & 93.4 & 92.7 & 94.1 & 93.8 & 93.0 & 92.8 & 92.8 & 93.1 & 93.1 & 92.8 & 93.1 & 93.1 & - & & & & & & & & \\
\hline 14 & Diploneis cf. smithii KSA2015-30 oval-B6 & 94.5 & 93.8 & 95.2 & 94.9 & 93.5 & 93.4 & 93.4 & 93.6 & 93.6 & 93.4 & 93.6 & 93.6 & 96.5 & & & & & & & & \\
\hline 15 & Diploneis cf. smithii GU44AY6 & 93.1 & 92.3 & 94.4 & 93.8 & 92.1 & 91.8 & 91.8 & 92.2 & 92.2 & 91.3 & 92.2 & 92.2 & 95.7 & 98.7 & - & & & & & & \\
\hline 16 & Diploneis parca KSA2015-49 oval-ED-2 & 93.6 & 92.9 & 93.8 & 93.5 & 92.4 & 92.1 & 92.1 & 92.4 & 92.4 & 92.1 & 92.4 & 92.4 & 96.5 & 98.1 & 96.0 & - & & & & & \\
\hline 17 & Diploneis sp. PackChannelPlank Diplo-1 & 95.1 & 94.4 & 95.5 & 95.2 & 93.5 & 93.4 & 93.4 & 93.6 & 93.6 & 93.4 & 93.6 & 93.6 & 95.5 & 97.1 & 95.2 & 96.7 & - & & & & \\
\hline 18 & Diploneis sp. KSA2015-14 oval-J31 & 94.0 & 93.2 & 94.1 & 93.8 & 93.0 & 92.8 & 92.8 & 93.1 & 93.1 & 92.8 & 93.1 & 93.1 & 96.8 & 98.7 & 97.0 & 99.5 & 96.8 & - & & & \\
\hline 19 & Diploneis sp. 21IV14-2A oval penn-B1 & 93.7 & 92.9 & 94.4 & 94.1 & 93.3 & 93.1 & 93.1 & 93.4 & 93.4 & 93.1 & 93.4 & 93.4 & 97.6 & 98.4 & 97.0 & 98.6 & 96.5 & 99.2 & - & & \\
\hline 20 & Diploneis subovalis UTEX FD282 & 92.6 & 92.1 & 92.8 & 92.7 & 91.9 & 91.4 & 91.5 & 91.7 & 91.7 & 91.4 & 91.7 & 91.7 & 96.3 & 97.3 & 96.1 & 97.0 & 95.7 & 97.1 & 96.8 & - & \\
\hline 21 & Diploneis vacillans KSA2015-11 peanut-E14 & 94.8 & 94.1 & 95.5 & 95.2 & 94.1 & 93.9 & 93.9 & 94.2 & 94.2 & 93.9 & 94.2 & 94.2 & 96.8 & 99.2 & 99.1 & 97.8 & 96.8 & 98.4 & 98.7 & 96.8 & - \\
\hline
\end{tabular}

60-68 in $10 \mu \mathrm{m}$. A narrow hyaline area separates the striae on the valve face from the mantle.

Internally (Figs 82-85), the raphe has straight proximal raphe ends that terminate at an indistinct central nodule, and distal ends that terminate as small helictoglossae.
Areolae are round to ellipsoidal, smaller in size from the external openings.

\section{Molecular investigation}

Studied strains presented low similarities to Diploneis species, and the evolutionary distance matrix based on 
the partial 18S rRNA gene including the V4 barcoding subregion showed that two Nupela indonesica strains shared $99.6 \%$ similarity with each other, but they shared 98.4\%-98.7\% similarities with Nupela lesothensis strains, 91.2\%-93.1\% similarities with Diploneis species, and $89.5 \%-91.8 \%$ similarities with Neidium species (Table 3). Simultaneously, the evolutionary distance matrix showed that Neidium species shared $97.7 \%-99.7 \%$ similarity with maximum value for Neidium affine (Ehrenberg) Pfitzer and Neidium longiceps (W. Gregory) R. Ross, 93.0\%-97.9\% similarity for Diploneis strains with maximum for Diploneis sp. 21IV14-2A oval penn-B1 and Diploneis vacillans KSA2015-11 peanut-E14 (Table 3).

Pairwise comparisons with putatively related taxa showed that strains of Nupela indonesica were 99.7\% similar, however they shared $97.7 \%-98.1 \%$ similarities with Nupela lesothensis strains and less than $95.1 \%$ amino acids similarity of ribulose-1,5-bisphosphate carboxylase with other diatoms in the analysis (Table 4). The percent similarity among aligned amino acids between Neidium species was available with a range of 98.6-100\%.

In the phylogenetic tree the four strains of Nupela investigated here are more closely related to each other than to any other taxa, and this single branch has high statistical support (see Fig. 86). This clade was identical in the Maximum Likelihood (Supplement S3) and Bayesian (Fig. 86) trees. This lineage of Nupela taxa is most closely related to the monophyletic group of Diploneis taxa, and together the lineage of Nupela and Diploneis are more closely related to a lineage comprised of two strains of Biremis. However these branches have poor statistical support. The monophyletic group of Nupela + Diploneis + Biremis is sister to a monohyletic group that includes Neidium + Scoliopleura (considered in the family Neidiaceae, Cox 2015) + Brachysira + Luticola strains + Diadesmis sensu stricto (considered in the family Diadesmdiaceae, Cox 2015). The Brachysiraceae is not recovered as a monophyletic group in this analysis. Molecular investigation of the new strain from the genus Brachysira is included to analysis (LM pictures see Figs 73-77). Other families that have in the past been considered part of the suborder Neidiineae D.G. Mann, represented here by the family Amphipleuraceae (with species Frustulia spp., Amphipleura) and Berkeleyaceae (with species Berkeleya spp., and Climaconeis spp.) are widely separated from suborder in this analysis (see Fig. 86).

\section{DiscUSSION}

Two Nupela species are included in this investigation. These are Nupela indonesica, described here as a new species, and Nupela lesothensis (Schoeman) LangeBertalot (see Figs 42-72, 78-85). These two species are similar in having lanceolate valves with protracted ends, but they can be distinguished from one another on the basis number of striae and number of areolae in $10 \mu \mathrm{m}$
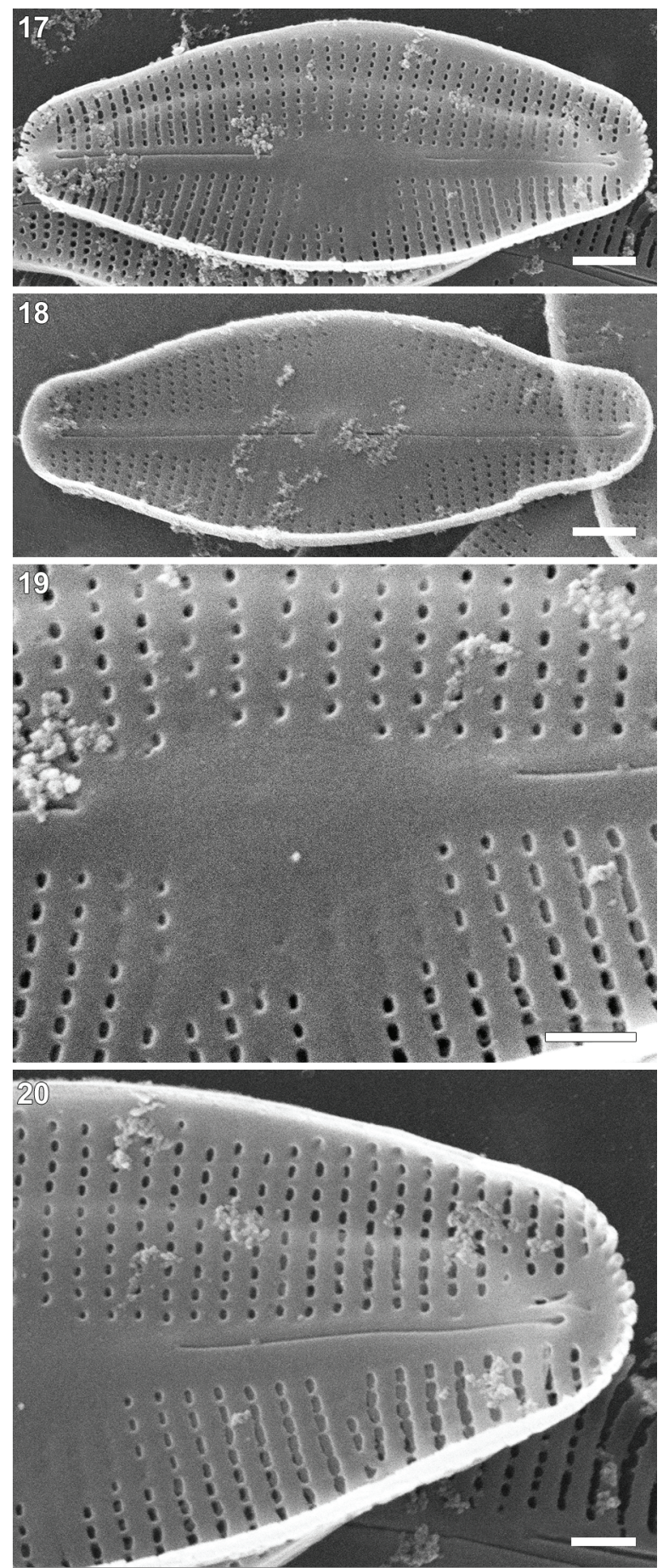

Figs 17-20. Nupela indonesica Kulikovskiy, Maltsev, Glushchenko et Kociolek sp. nov. Strain Ind 121. SEM, internal views. $(17,18)$ the whole valve; (19) central area; (20) valve end. Scale bars $1 \mu \mathrm{m}$ $(17,18), 0.5 \mu \mathrm{m}(19,20)$.

(see Table 2). Calculated evolutionary distances for the barcoding subregion V4 of the 18S rRNA gene and amino acid sequence of ribulose-1,5-bisphosphate carboxylase provides strong evidence for Nupela indonesica being in a separate species from Nupela lesothensis, since for example the intraspecies percent dissimilarity for Neidium species being $0.3 \%-2.3 \%$ (V4) or $<1.4 \%$ (rbcL).

These species were isolated from Bali and Sulawesi 


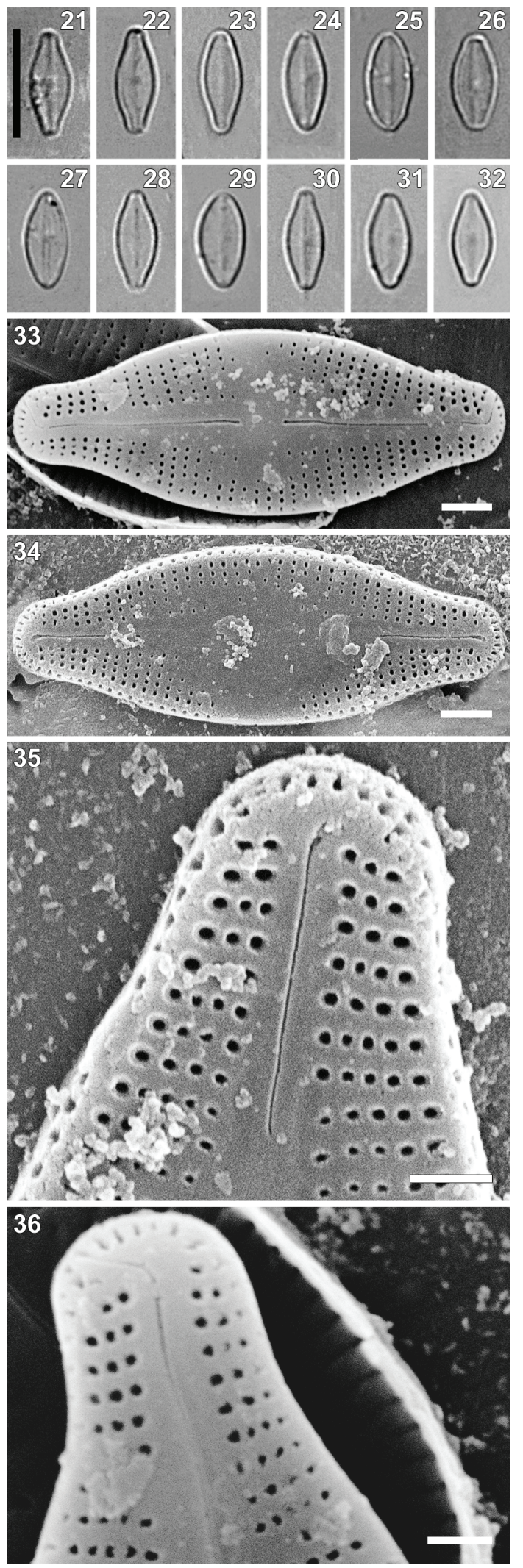

Figs 21-36. Nupela indonesica Kulikovskiy, Maltsev, Glushchenko et Kociolek sp. nov. Strain Ind 219. Slide no 01858. (21-32)LM, DIC, size diminution series, (33-36) SEM, external views, $(33,34)$ the whole valve, $(35,36)$ valves ends. Scale bars $10 \mu \mathrm{m}(21-32), 2$ $\mu \mathrm{m}(33,34), 0.5 \mu \mathrm{m}(35,36)$.
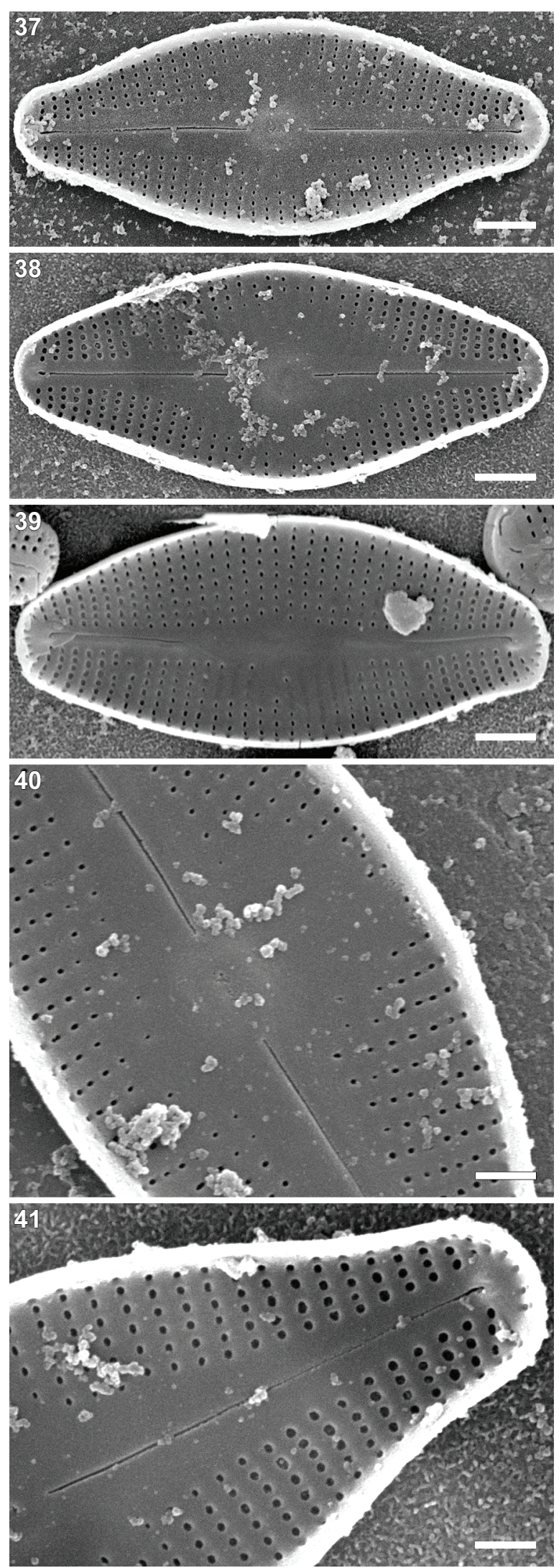

Figs 37-41. Nupela indonesica Kulikovskiy, Maltsev, Glushchenko et Kociolek sp. nov. Strain Ind 219. SEM, internal views. (37-39) the whole valve; (40) central area; (41) valve end. Scale bars $1 \mu \mathrm{m}$ (37-39), $0.5 \mu \mathrm{m}(40,41)$. 

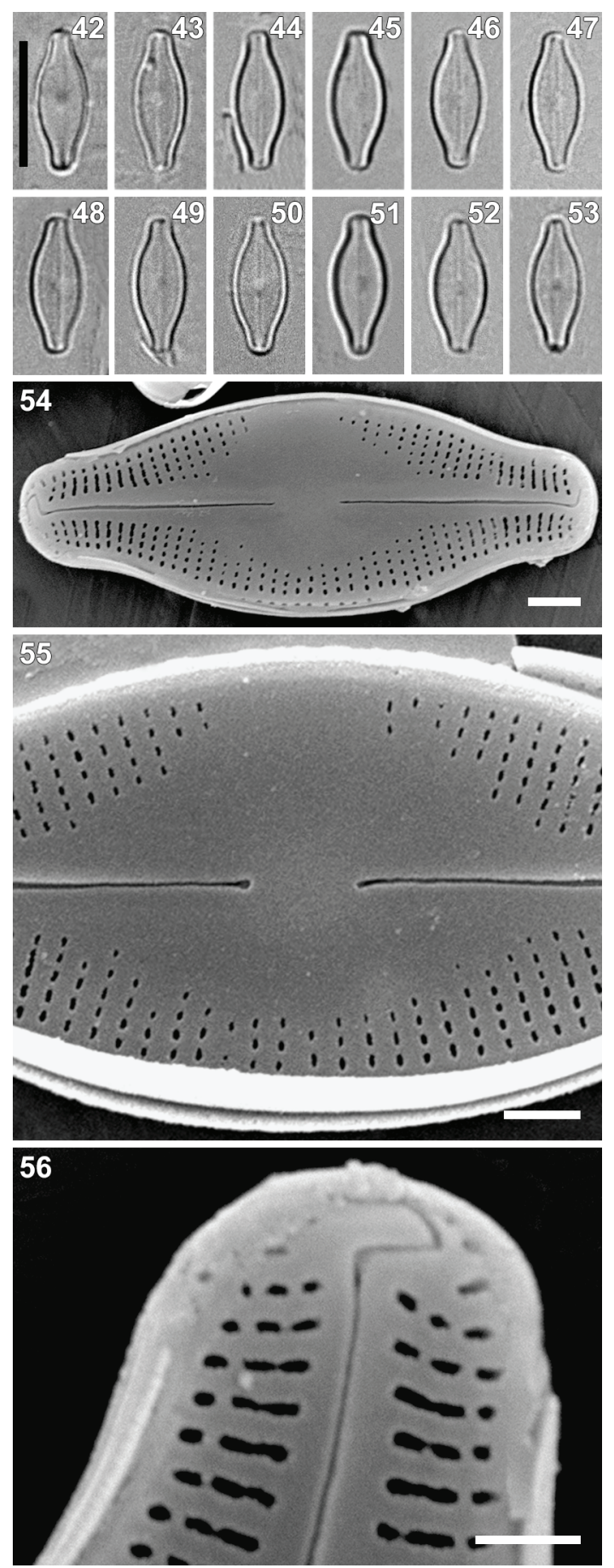

Figs 42-56. Nupela lesothensis (Schoeman) Lange-Bertalot. Strain Ind 168. Slide no 01713. (42-53) LM, DIC, size diminution series; (54-56)SEM, external views, (54) the whole valve, (55) central area, (56) valve end. Scale bars $10 \mu \mathrm{m}(42-53), 1 \mu \mathrm{m}(54,55), 0.5 \mu \mathrm{m}$ (56).

Islands in Indonesia. $N$. indonesica sp. nov. is distinguished from other known species of Nupela, such as the morphologically-similar species Nupela giluwensis, $N$. biconfusa and $N$. praecipuoides, on the basis of the shape of valves and especially number of striae, areolae in $10 \mu \mathrm{m}$ and number of areolae per stria (see Table 2). Specimens of $N$. lesothensis from our material conform to the type description of this species given by SCHOEMAN
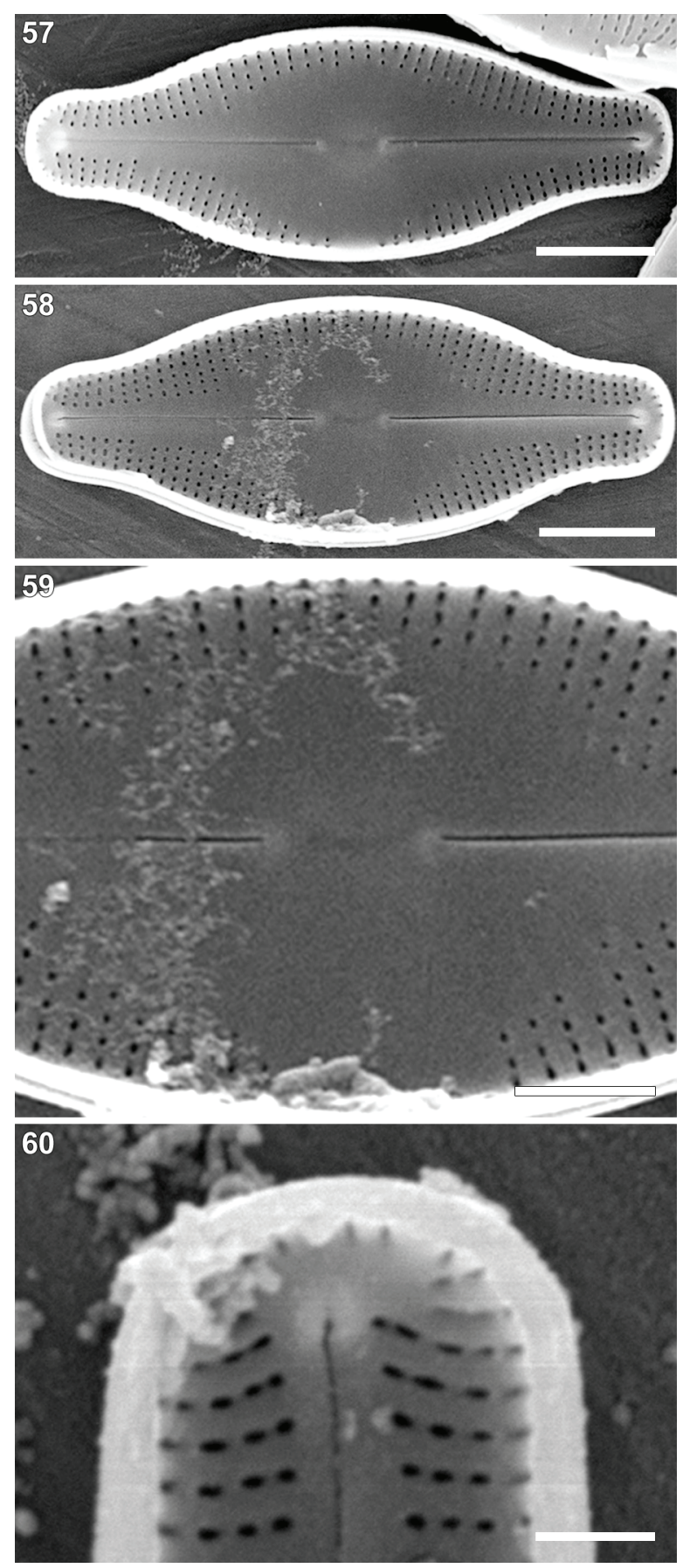

Figs 57-60. Nupela lesothensis (Schoeman) Lange-Bertalot. Strain Ind 168 . SEM, internal views. $(57,58)$ the whole valve; $(59)$ central area; (60) valve end. Scale bars $2 \mu \mathrm{m}(57,58), 1 \mu \mathrm{m}(60), 0.5 \mu \mathrm{m}$ (59).

(1973) on the basis of shape as well as striae and areolae density. This species was originally described by Schoeman from a spring and its effluent stream at Paballong near Mamathe in the Berea district of Lesotho, and known also from Italy, Seychelles, Africa southern and south-western, Germany, Munich, Botanical Gardens and South America (see Wojtal 2009; Rumrich et al. 2000; SALA et al. 2014). These data show that this species is widespread.

The phylogenetic position of Nupela, as represented 

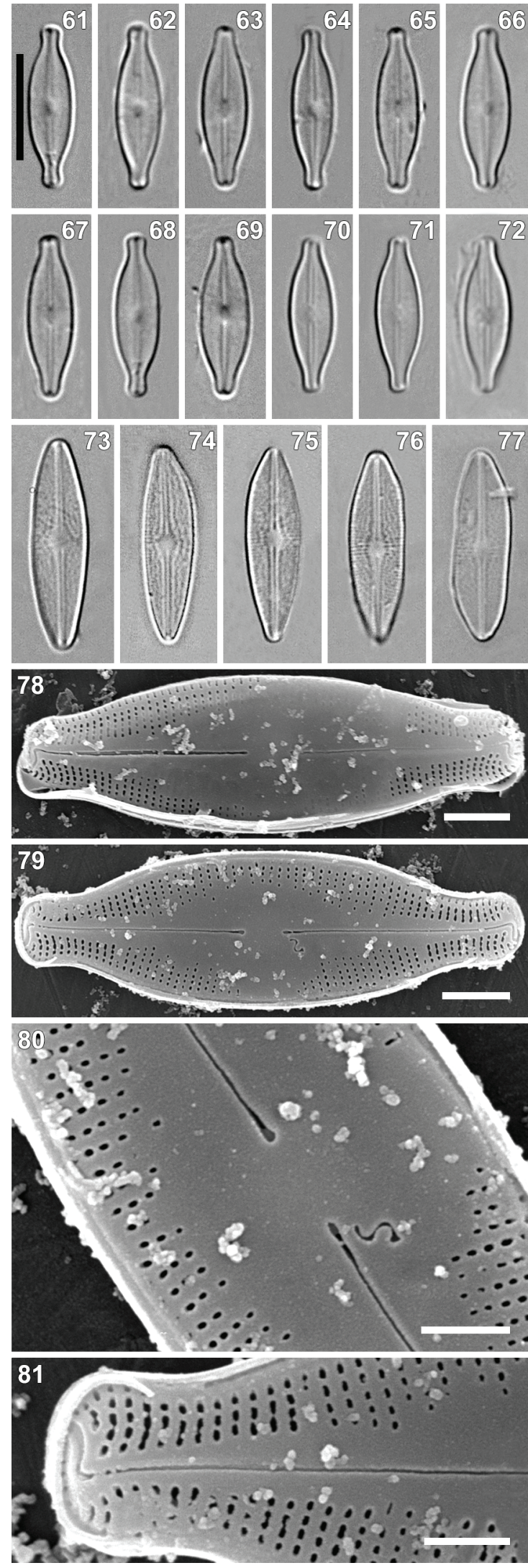

Figs 61-81. Nupela lesothensis (Schoeman) Lange-Bertalot (Strain Ind 170, slide no 01688) and Brachysira sp. (Strain VN 374, slide no 04582). (61-77)LM, DIC, size diminution series; (78-81) SEM, external views, $(78,79)$ the whole valve, $(80)$ central area, $(81)$ valve end. Scale bars $10 \mu \mathrm{m}$ (61-77), $2 \mu \mathrm{m}$ (78), $1 \mu \mathrm{m}(79,80)$.
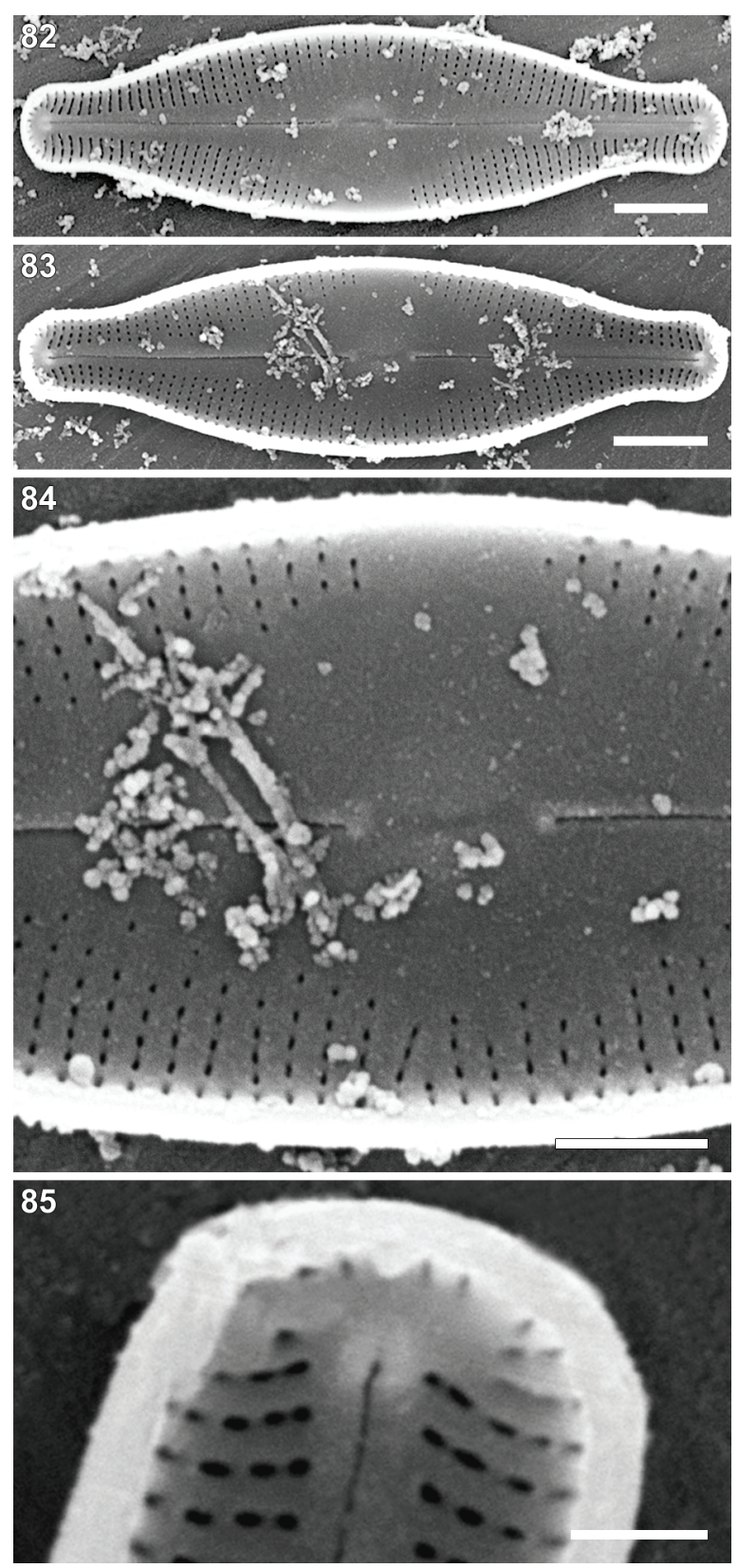

Figs 82-85. Nupela lesothensis (Schoeman) Lange-Bertalot. Strain Ind $170 . \mathrm{SEM}$, internal views. $(82,83)$ the whole valve; $(84)$ central area; (85) valve end. Scale bars $2 \mu \mathrm{m}(82,83), 1 \mu \mathrm{m}(84,85)$.

by these two taxa from SE Asia, suggest they are part of a lineage that includes Diploneis and Biremis, rather than any group assigned to the Neidiineae. Strains of Nupela occur in one cluster that is sister to a branch of Diploneis species (Fig. 86). Diploneis as a genus that belongs to the family Diploneidaceae D.G. Mann and suborder Diploneidineae D.G. Mann (Cox 2015). And Biremis, which had previously been assigned to Scoliotropidaceae (Round et al. 1990), also does not appear to be part of the Neidiineae. Our data do not support the idea of Cox (2015) that Nupela as a genus is closely to Brachysira, another group that had been included in the Neidiineae, but that falls outside the Neidiineae, and is not closely related to Nupela. In other words, the only way for the 


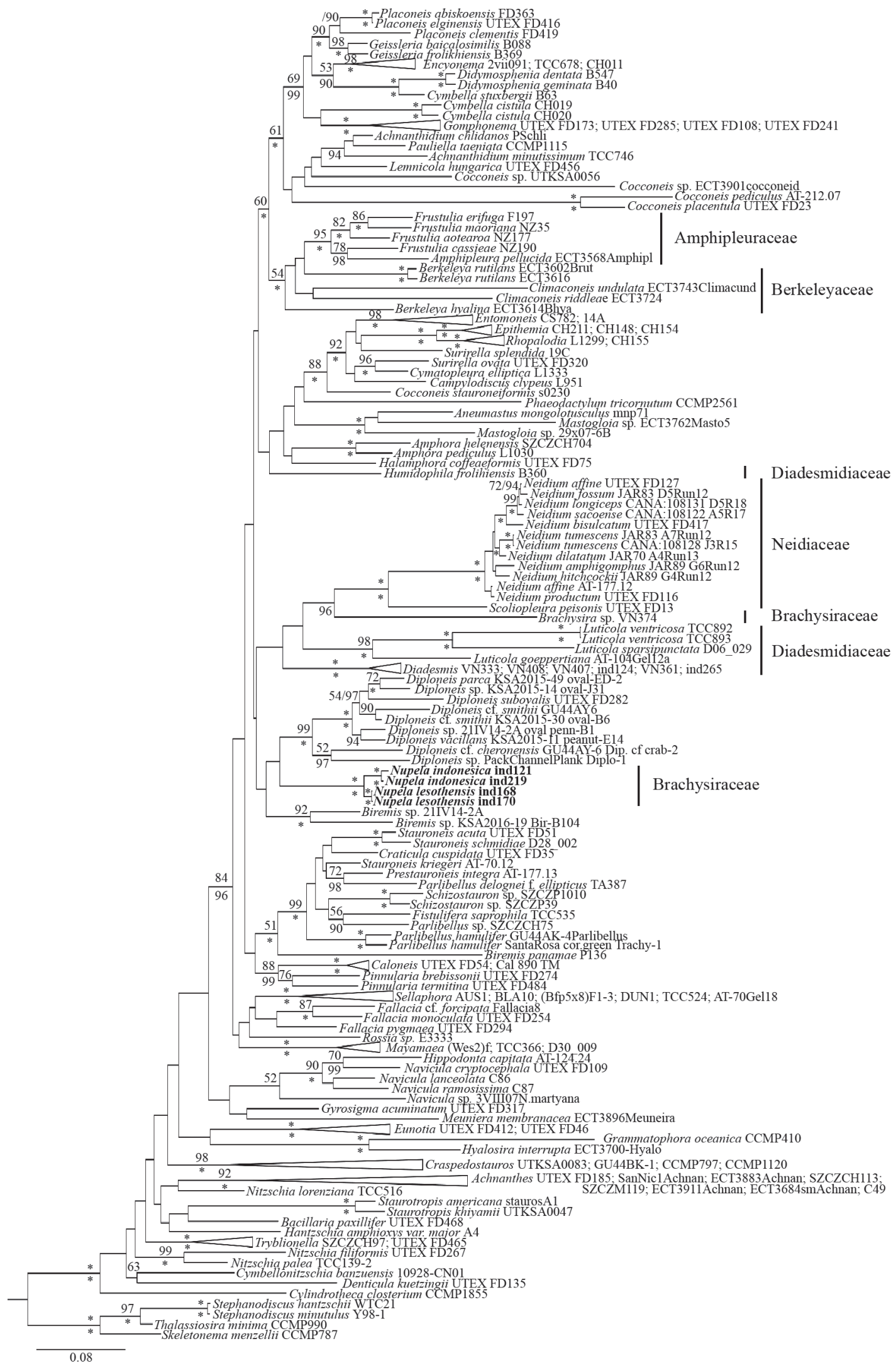

Fig. 86. Bayesian tree of Nupela species (indicated in bold) constructed from a concatenated alignment of 163 partial rbcL and partial 18S rDNA sequences of 1806 characters. Values above the horizontal lines (slash) are bootstrap support from RAxML analyses ( $<50$ are not shown); values below the horizontal lines (slash) are Bayesian posterior probabilities ( $<90$ are not shown). Species from the centric diatoms were used as an outgroup. * is $100 \%$ statistical support. Families indicated according Cox (2015). 
Neidiineae to be a monophyletic group and to include Nupela in it, would be to include Diploneis and Biremis in this suborder. Our investigation does not support idea that Nupela belongs to the family Brachysiraceae sensu Cox (2015). Of course, increased taxon sampling of both Brachysira and Nupela, as well as other raphid diatom groups, is needed, but the current molecular analysis presented here shows that Nupela is distantly related to Brachysira.

Features that diagnose the genus Nupela are related to the morphology of areolae and pore occlusions, with areolae being larger externally then internally and covered by hymenes externally. Presence of external hymenes is known only for this genus among the pennate diatoms; it is absent from other pennate diatoms (PotAPova 2011). However, Nupela and Brachysira do have a similar structure of hymenes that POTAPOVA (2011) identified as coalescing hymenes (see PotaPova 2011; Round et al. 1990). This type of hymen exceeds the boundary of individual areolae and is organized into a total belt with more elongated shape inside the areolae in Brachysira and more kidney-like on the exterior of the areolae in Nupela (see Potapova 2011; Round et al. 1990).

This analysis shows that several families assigned to the suborder Neidiineae sensu Cox are not part of a monophyletic group to the exclusion of other families. For example, both the Amphipleuraceae and Berkeleyaceae are sister taxa and combined to form independent lineage without high statistical support; they do not form a monophyletic group with members of the Neidiineae. Another cluster that is part of a monophyletic lineage that includes the Neidiaceae, has both the Brachysiraceae (including just the genus Brachysira) and Diadesmidiaceae (with genera Luticola and Diadesmis). Interestingly, Humidophila and Diadesmis are not sister genera on the basis molecular investigation, and the phylogenetic position of first genus needs investigation in the future with a greater number of strains. Thus, we can conclude that families originally assigned to the suborder Neidiineae as proposed by D.G. Mann actually represent at least four independent lineages. Several families as of yet do not have molecular sequence data represented for them (e.g. Cavinulaceae, Cosmioneidaceae).

Nupela indonesica sp. nov. is very interesting on the basis heterovalvy with respect to raphe development on a frustule. In our material strains of $N$. indonesica sp. nov. produced frustules with one valve with a fully-developed raphe and a short central nodule (see Figs 13, 18,33 ) and the other valve with a short raphe with longer central nodule (see Figs 20, 34, 35, 39). Presence of reduced raphes in the genus Nupela is well documented, especially from Lake Baikal (Kulikovskiy et al. 2015, 2016). These data suggest that presence or absence of a raphe is very facultative feature; the genus Sinoperonia (LIU et al. 2018) may be the most extreme example of this phenomenon. From a phylogenetic point of view, these data provide evidence that instability in raphe development occurred both early in the development of raphid diatom phylogeny (e.g. Eunotiales), as well as through secondary loss in taxa that belong now to Stauroneiaceae, Achnanthaceae and Achnanthidiaceae (Cox 2015; Kociolek et al. 2019; KulikovskiY et al. 2019).

Presence of the monoraphid condition between suborder Neidiineae was shown perfectly by Cox (2006, 2012) who investigated raphe instability in Diadesmis gallica that now transferred to a new genus Humidophila (Lowe et al. 2014). Cox (2015) combined Humidophila and Diadesmis to a joint family Diadesmidiaceae. However, in our molecular investigation Humidophila is organized as an independent branch with lower statistical support with the genera Amphora and Halamphora (see Fig. 86), and phylogenetic position of Humidophila will need more careful investigation in future with more available strains. The same results about phylogeny of the genus Humidophila was shown by NAKOV et al. (2019) who showed it in an unresolved position between the Stauroneiaceae and Neidiaceae. These data support the idea that raphe instability, in terms of size, structure and number is common among different evolutionary lineages of pennate diatoms.

\section{ACKNOWLedgements}

Authors are grateful to the staff of the Centre of Electron Microscopy of the Papanin Institute for Biology of Inland Waters, RAS, for technical assistance. Publication is based on research carried out with financial support by Russian Science Foundation (19-14-00320) for LM, SEM, sample investigation and by framework of the state assignment (theme AAAA-A19-119041190086-6) for finishing the manuscript.

\section{REFERENCES}

BAHLS, L.L. (2011): Nupela potapovae sp. nov. (Bacillariophyta), a lentic alpine species from North America - Diatom Research 26: $167-174$

Buczkó, K.; WoJTAL, A.Z. \& MAgYaRI, E.K. (2013): Late quaternary Nupela taxa of Retezat Mts (S. Carpathians), with description of Nupela pocsii sp. nov. (Bacillariophyceae). - Polish Botanical Journal 58: 427-436.

Cox, E J. (2006): Raphe loss and spine formation in Diadesmis gallica (Bacillariophyta) - an intriguing example of phenotypic plasticity in a diatom. - Nova Hedwigia Beihefte 130: 163-76.

Cox, E.J. (2015): Coscinodiscophyceae, Mediophyceae, Fragilariophyceae, Bacillariophyceae (Diatoms). - In: JAKLITSCH, W.; BARAL, H.O.; LÜCKING, R.; LumbSCH, H.T. \& Frey, W. (eds): Syllabus of Plant Families. Adolf Engler's Syllabus der Pflanzenfamilien. Part 2/1. Photoautotrophic eukaryotic Algae: Glaucocystophyta, Cryptophyta, Dinophyta/Dinozoa, Haptophyta, Heterokontophyta/ Ochrophyta, Chlorarachniophyta/Cercozoa, Euglenophyta/ Euglenozoa, Chlorophyta, Streptophyta. - pp. 64-103, Borntraeger Verlagsbuchhandlung, Stuttgart.

Falasco, E.; Bona, F.; Isaia, M.; Piano, E.; Wetzel, C.E.; Hoffmann, L. \& Ector L. (2015): Nupela troglophila sp. nov., an aerophilous diatom (Bacillariophyta) from the Bossea cave (NW Italy), with notes on its ecology. - Fottea 15: 1-9.

Fourtanier, E. \& KocioleK, J.P. (2011): Catalogue of Diatom Names. - California Academy of Sciences, Online Version, accessed 19 Sep 2011. http://researcharchive.calacademy.org/research/ diatoms/names/index.asp.

Genkal, S.I. \& VeKHOV, N.V. (2007): Diatoms of the reservoirs of the Russian Arctic; archipelago Novaya Zemlya and Vaigach Island. - pp. 1-64, Nauka Press, Moscow.

GuIRY, M.D. \& GuIRY, G.M. (2020): AlgaeBase. World-wide electronic 
publication, National University of Ireland, Galway. https:// www.algaebase.org/search/genus/detail/?genus_id=43732\&-se ssion=abv4:AC1F05EC161332C951pg97CE630A, searched on 5 March 2017.

KocioleK, J.P.; Williams, D.M.; StePaneK, J.; LiU, Q.; LiU, Y.; YoU, Q-M.; Karthick, B. \& KulikovskiY, M. 2019. Rampant homoplasy and adaptive radiation in pennate diatoms. - Plant Ecology and Evolution 152: 131-141.

Kulikovskiy, M.S.; Glushchenko, A.M.; KuZnetsova, I.V. \& GenKal, S.I. (2016): Identification book of diatoms from Russia. - pp. 1-804, Filigran, Yaroslavl. (In Russ.).

Kulikovskiy, M.S.; LAnge-Bertalot, H. \& Witkowski, A. (2009): Nupela matrioschka sp. nov., Nupela thurstonensis comb. nov. and Nupela neogracillima comb. \& nom. nov. (Bacillariophyceae): critical analysis of their morphology. Polish Botanical Journal 54: 13-20.

Kulikovskiy, M.S.; Maltsev, Ye.I.; Andreeva, S.A.; Glushchenko, A.M.; Gusev, E.S.; PodunaY, Yu.A.; Ludwig, T.V.; Tusset, E. \& Kociolek, J.P. (2019): Description of a new diatom genus Dorofeyukea gen. nov. with remarks on phylogeny of the family Stauroneidaceae. - Journal of Phycology 55: 173-185.

LANGE-BERTALOT, H. (1993): 85 neue taxa und uber 100 weitere neu definierte Taxa erganzeng zur Sußwasserflora von Mitteleuropa. - Bibliotheca Diatomologica 27: 1-454.

Lange-Bertalot, H. \& Genkal, S.I. (1999): Diatoms from Siberia I. Islands in the Arctic Ocean (Yugorsky-Shar Strait). Iconographia Diatomologica 6: 1-292.

Lange-Bertalot, H. \& Moser, G. (1994). Brachysira. Monographie der Gattung. - Bibliotheca Diatomologica 29: 1-212.

Lowe, R.L.; Kociolek, J.P.; Johansen, J.R.; Van de ViJver, B.; Lange-Bertalot, H. \& Kopalová, K. (2014): Humidophila gen. nov., a new genus for a group of diatoms (Bacillariophyta) formerly within the genus Diadesmis: species from Hawai'i, including one new species. - Diatom Research 29: 351-360.

LiU, Y.; Kociolek, J.P.; Wang, Q. \& Fan, Y. (2014): Two new species of monoraphid diatom (Bacillariophyceae) from South of China. - Phytotaxa 188: 31-37.

Metzeltin, D. \& Lange-Bertalot, H. (1998): Tropical diatoms of South America I: About 700 predominantly rarely known or new taxa representative of the neotropical flora. - Iconographia Diatomologica 5: 1-695.

Metzeltin, D. \& Lange-Bertalot, H. (2007): Tropical Diatoms of South America II: Special Remarks on Biogeographic Disjunction. - Iconographia Diatomologica 18: 1-877.

Monnier, O.; Lange-Bertalot, H. \& Bertrand, J. (2003): Nupela exotica species nova: une diatomée d'un aquarium tropical d'eau douce. Avec des remarques sur la biogéographie du genre. - Diatom Research 18: 273-291.

Moser, G.; Lange-Bertalot, H. \& Metzeltin, D. (1998): Insel der Endemiten. Geobotanisches Phänomen Neukaledonien. Bibliotheca Diatomologica 38: 1-464.

Nakov, T.; Beaulieu, J.M. \& Alverson, A.J. (2019): Accelerated diversification is related to life history and locomotion in a hyperdiverse lineage of microbial eukaryotes (Diatoms, Bacillariophyta). - New Phytologist 219: 462-473.

Potapova, M.G. (2011). New species and combinations in the genus Nupela from the USA. - Diatom Research 26: 73-87.

Potapova, M.G. (2013): Transfer of Achnanthes decipiens to the genus Nupela. - Diatom Research 28: 139-142.

Potapova, M.G.; Ponader, K.C.; Lowe, R.L.; Clason, T.A. \& BAHLS, L.L. (2003): Small-celled Nupela species from North America. - Diatom Research 18: 293-306.

Round, F.E.; Crawford, R.M. \& Mann, D.G. (1990): The Diatoms. Biology and morphology of the genera. - pp. 1-747, Cambridge University Press, Cambridge.

Rumrich, U.; Lange-Bertalot, H. \& Rumrich, M. (2000): Diatoms of the Andes from Venezuela to Patagonia/Tierra del Fuego and two additional contributions. - Iconographia Diatomologica 9: 1-671.

Sala, S.; Vouilloud, A.A.; Plata-Díaz, Y.; Pedraza, E. \& Pimienta, A. (2014): Nupela species (Naviculales: Bacillariophyceae) from Colombian lowland waters inculding $N$. acaciensis nov. sp. and N. catatumbensis nov. sp. - Revista de Biología
Tropical 62: 241-255.

Schoeman, F.R. (1973): A systematical and ecological study of the diatom flora of Lesotho with special reference to the water quality. - pp. 1-355, V \& R Printers, Pretoria.

Siver, P.A.; Hamilton, P.B. \& Morales, E.A. (2007): Notes on the genus Nupela (Bacillariophyceae) including the description of a new species, Nupela scissura sp. nov. and an expanded description of Nupela paludigena. - Phycological Research 55: $125-134$.

Siver, P.A.; Wolfe, A.P. \& Edlund, M.B. (2010): Taxonomic description and evolutionary implications of Middle Eocene pinnate diatoms representing the extend genera Oxyneis, Actinella and Nupela (Bacillariophyceae). - Plant Ecology and Evolution 143: 340-351.

Tremarin, P.I.; Straube, A. \& Ludwig, T.A.V. (2015): Nupela (Bacillariophyceae) in littoral rivers from south Brazil, and description of six new species of the genus. - Fottea 15: 75-93.

Vyverman, W. \& Compère, P. (1991): Nupela giluwensis gen. \& spec. nov. A new genus of naviculoid diatoms. - Diatom Research 6: 175-179.

Wojtal, A.Z. (2009): Nupela marvanii sp. nov., and N. lapidosa (Krasske) Lange-Bertalot in Poland with notes on the distribution and ecology of the genus Nupela (Bacillariophyta). - Fottea 9: 233-242.

Yu, P.; You, Q.; KocioleK, J.P.; Lowe, R. \& Wang, Q. (2017): Nupela major sp. nov., a new diatom species from Maolan nature Reserve, central-south of China. - Phytotaxa 311: 245-254.

Supplementary material

The following supplementary material is available for this article:

Table S1. Taxa and DNA sequence data used in phylogenetic analysis.

This material is available as part of the online article (http:// fottea.czechphycology.cz/contents)

Genetic data and underlying taxa and GenBank sources of diatoms used in phylogenetic analysis for the diatom genus Nupela [Data set]. Zenodo. http://doi.org/10.5281/zenodo.3862169

Supplement S2. Final alignment of 2-gene DNA sequence data used for phylogenetic analysis in FASTA format.

Supplement S3. Maximum Likelihood tree of Nupela species (indicated in bold) constructed from a concatenated alignment of 163 partial $r b c \mathrm{~L}$ and partial $18 \mathrm{~S}$ rDNA sequences of 1806 characters. Values near the horizontal lines (slash) are bootstrap support from RAxML analyses $(<50$ are not shown). Species from the centric diatoms were used as an outgroup. Families indicated according Cox (2015)

(C) Czech Phycological Society (2020)

Received March 24, 2020

Accepted June 8, 2020 